\title{
Improved Tumor Targeting of Radiolabeled RGD Peptides Using Rapid Dose Fractionation
}

\author{
Marcel Janssen, ${ }^{1,2}$ Cathelijne Frielink, ${ }^{1}$ Ingrid Dijkgraaf, ${ }^{1}$ Wim Oyen, ${ }^{1}$ D. Scott Edwards, ${ }^{3}$ \\ Shuang Liu, ${ }^{3}$ Milind Rajopadhye, ${ }^{3}$ Leon Massuger, ${ }^{2}$ Frans Corstens, ${ }^{1}$ and Otto Boerman ${ }^{1}$ \\ Departments of ${ }^{1}$ Nuclear Medicine and ${ }^{2}$ Gynecology, University Medical Center Nijmegen, Nijmegen, \\ The Netherlands; ${ }^{3}$ Bristol-Myers Squibb Medical Imaging, Billerica, MA
}

\begin{abstract}
Arginine-glycine-aspartic acid (RGD) peptides preferentially bind to $\alpha_{v} \beta_{3}$ integrin, an integrin expressed on newly formed endothelial cells and on various tumor cells. When labeled with $\beta$-emitting radionuclides, these peptides can be used for peptide-receptor radionuclide therapy of malignant tumors. These studies aimed to investigate whether tumor targeting and tumor therapy could be optimized by dose fractionation.

The RGD-peptide DOTA-E- $[c(R G D f K)]_{2}$ was labeled with ${ }^{111}$ In for biodistribution experiments and with ${ }^{90} Y$ for therapy experiments. In mice with NIH:OVCAR-3 ovarian carcinoma xenografts, optimal tumor uptake was obtained at peptide doses up to $1.0 \mu \mathrm{g}(4.8 \% \mathrm{ID} / \mathrm{g})$. A peptide dose of $5 \mu \mathrm{g}$, required to administer the maximum tolerable dose (MTD) ${ }^{90} Y-D O T A-E-[c(R G D f K)]_{2}$, was administered as 5 portions of $1.0 \mu \mathrm{g}$. Tumor uptake of the fifth portion was significantly higher than that of the single $5.0 \mu \mathrm{g}$ portion $(3.3 \% I D / g$ versus $2.1 \% I D / g)$. The therapeutic efficacy of $37 \mathrm{MBq}{ }^{90} Y$-DOTA-E- $[c(R G D f K)]_{2}$ $(1 \times 5.0 \mu \mathrm{g})$ was compared with that of $37 \mathrm{MBq}$ administered in five equal portions $(5 \times 1.0 \mu \mathrm{g})$. No difference in tumor growth between the fractionated and the nonfractionated therapy was observed. In conclusion, dose fractionation resulted in higher radiation doses. However, therapeutic efficacy of the radiolabeled peptide was not significantly improved by dose fractionation.
\end{abstract}

Key words: RGD peptides, $\alpha_{\mathrm{v}} \beta_{3}$ integrin, tumor targeting, dose fractionation

\section{INTRODUCTION}

Integrins are a group of adhesion molecules consisting of two noncovalently bound transmembranous subunits $\left(\alpha\right.$ and $\beta$ ). Integrin $\alpha_{\mathrm{v}} \beta_{3}$ mediates cellular adhesion to extracellular matrix proteins (e.g., vitronectin, fibrinogen, laminin,

Address reprint requests to: Otto Boerman; Department of Nuclear Medicine, University Medical Center Nijmegen; P.O. Box 9101, $6500 \mathrm{HB}$ Nijmegen, The Netherlands; Tel.: +31-24-3613813; Fax: +31-24-3618942

E-mail: O.Boerman@nucmed.umcn.nl collagen) through exposed tripeptide arginineglycine-aspartic acid (RGD) amino-acid moieties. ${ }^{1}$ Integrin $\alpha_{\mathrm{v}} \beta_{3}$ is preferentially expressed on proliferating endothelial cells. ${ }^{2}$ For their growth beyond a certain size, tumors are dependent on the formation of new blood vessels from preexisting capillaries (angiogenesis) and thus $\alpha_{\mathrm{v}} \beta_{3}$ is expressed on the blood vessels of most growing tumors. ${ }^{3-5}$ In addition, $\alpha_{\mathrm{v}} \beta_{3}$ is expressed on various tumor cell types (ovarian cancer, neuroblastoma, breast cancer, melanoma, and others). Due to the restricted expression of $\alpha_{\mathrm{v}} \beta_{3}$ in tumors, $\alpha_{\mathrm{v}} \beta_{3}$ is considered a suitable membrane structure for tumor targeting. ${ }^{6}$ 
The potential of $\alpha_{\mathrm{v}} \beta_{3}$-binding peptides to serve as vehicles for targeting tumors with radionuclides has been investigated by several groups. Haubner et al. studied two radioiodinated cyclic pentapeptides (c(RGDyV) and $\mathrm{c}(\mathrm{RGDfY}) ; \mathrm{IC}_{50}=$ $2 \mathrm{nM}$ ) in nude mice with various tumors. ${ }^{7}$ Tumor uptake peaked 10 minutes after injection (3.50 \pm $0.73 \% \mathrm{ID} / \mathrm{g}$ ). Both peptides mainly cleared via the hepatobiliary route. Subsequently, they synthesized a glycosylated version of $\mathrm{c}(\mathrm{RGDyK})$ that cleared predominantly via the kidneys. ${ }^{8}$ This compound $\left(\mathrm{IC}_{50}=40 \mathrm{nM}\right)$ had a longer circulatory half-life and a significantly reduced uptake in the liver ( 2 versus $10 \% \mathrm{ID} / \mathrm{g}$ at 1 hour postinjection [p.i.]). Most importantly, the glycosylated RGD-peptide had a clearly higher uptake in the tumor $(3.0 \pm 0.31 \% \mathrm{ID} / \mathrm{g}$ versus $0.92 \pm 0.16$ $\%$ ID/g at 4 hour p.i.). Van Hagen et al. studied the cyclic peptide $\mathrm{c}(\mathrm{RGDyK})$ conjugated with DTPA. ${ }^{9}$ Uptake of the ${ }^{111}$ In-labeled peptide in CA20948 pancreatic tumors in rats amounted to $0.2 \% \mathrm{ID} / \mathrm{g}$ at 24 hour p.i., while at this timepoint, the peptide was almost completely cleared from the blood $(0.003 \% \mathrm{ID} / \mathrm{g})$.

In our previous studies, we have shown that the radiolabeled c(RGDfK)-peptides specifically accumulated in $\alpha_{\mathrm{v}} \beta_{3}$-positive ovarian cancer xenografts in athymic mice. ${ }^{10}$ The dimeric RGD peptide was retained better in the tumor than the monomeric RGD peptide. ${ }^{11}$ The uptake of ${ }^{111}$ InDOTA-E-[c(RGDfK) $]_{2}$ in subcutaneous (s.c.) OVCAR-3 tumors peaked at $7.5 \% \mathrm{ID} / \mathrm{g} 2$ hour after intravenous injection. A single injection of this peptide labeled with ${ }^{90} \mathrm{Y}$ (37 MBq/mouse) caused a significant growth delay of the tumors. In the present study, the optimal peptide dose for peptide radionuclide therapy with the dimeric RGD peptides was determined. In addition, the effect of rapid dose fractionation on the radiation dose guided to the tumors and on the therapeutic efficacy was studied.

\section{MATERIALS AND METHODS}

\section{Radiolabeling of the RGD Peptide}

The synthesis and characterization of the dimeric cyclic RGD peptide E-[c(RGDfK) $]_{2}$ conjugated with the chelator 1,4,7,10-tetraazadodecane$\mathrm{N}, \mathrm{N}^{\prime}, \mathrm{N}^{\prime \prime}, \mathrm{N}^{\prime \prime \prime}$-tetraacetic acid (DOTA) was described previously. ${ }^{10,12,13}$ The peptide has a high affinity for the $\alpha_{\mathrm{v}} \beta_{3}$ integrin $\left(\mathrm{IC}_{50}=0.9 \mathrm{nM}\right)$. DOTA-E- $[\mathrm{c}(\mathrm{RGDfK})]_{2}$ was radiolabeled with ${ }^{111}$ In to obtain ${ }^{111}$ In-DOTA-E-[c(RGDfK) $]_{2}$.
Briefly, $250 \mu \mathrm{g}$ DOTA-E-[c(RGDfK) $]_{2}$ was dissolved in $4.5 \mathrm{~mL}$ of $0.25 \mathrm{M}$ ammoniumacetate buffer, $\mathrm{pH} 7.0$ and $160 \mathrm{MBq}{ }^{111} \mathrm{InCl}_{3}$ (Mallinckrodt, Petten, The Netherlands) was added. The mixture was heated for 15 minutes at $100^{\circ} \mathrm{C}$. The radiochemical purity was determined by reversedphase high-performance liquid chromatography (RP-HPLC) (HP 1100 series, Hewlett Packard, Palo Alto, CA) using a C18 column (RX-C18, $4.6 \times 250 \mathrm{~mm}$, Zorbax) eluted with an isocratic eluent $(13 \%$ acetonitrile in $25 \mathrm{mM}$ phosphate buffer, $\mathrm{pH} 6.0$ ) at $1.0 \mathrm{~mL} /$ minute. The radioactivity of the eluate was monitored using an in-line radiodetector (Radiomatic Flo-One Beta series A-500, Packard BioScience, Zellik, Belgium).

${ }^{90} \mathrm{Y}-\mathrm{DOTA}-\mathrm{E}-[\mathrm{c}(\mathrm{RGDfK})]_{2}$ was prepared by adding $2775 \mathrm{MBq}{ }^{90} \mathrm{YCl}_{3}$ (Perkin Elmer, Boston, MA) to $375 \mu \mathrm{g}$ of DOTA-E-[c(RGDfK) $)_{2}$ dissolved in $1.75 \mathrm{~mL}$ of $0.25 \mathrm{M}$ ammoniumacetate buffer, $\mathrm{pH}$ 6.0. The mixture was heated at $100^{\circ} \mathrm{C}$ for 15 minutes. Quality control was carried out as described for the ${ }^{111} \mathrm{In}$-labeled peptide. The scrambled sequence control peptide DOTA-E$[\mathrm{c}(\mathrm{RGKfD})]_{2}$ served as a control in the therapy experiments and was radiolabeled with ${ }^{90} \mathrm{YCl}_{3}$ analogously.

\section{Animal Model}

In our animal model, $0.2 \mathrm{~mL}$ of a cell suspension of NIH:OVCAR-3 human ovarian carcinoma cells $\left(5 \times 10^{7}\right.$ cells $\left./ \mathrm{mL}\right)$ was injected s.c. in the right flank of 6-8 week-old female nude BALB/c mice. The NIH:OVCAR-3 tumor cells express the $\alpha_{\mathrm{v}} \beta_{3}$ integrin. Two (2) weeks after inoculation of the tumor cells, when the diameter of the tumors was $6-8 \mathrm{~mm}$, the mice were i.v. injected with the radiolabeled peptides via the tail vein.

\section{Biodistribution Studies}

In these experiments, the effect of the peptide dose escalation and the effect of peptide dose fractionation on the biodistribution of the radiolabeled peptide was determined.

Five groups of five mice received 0.5, 1.0, 2.0, 5.0 , or $10 \mu \mathrm{g}$ of the DOTA-E-[c(RGDfK) $]_{2}$ peptide labeled with $0.4 \mathrm{MBq}{ }^{111} \mathrm{In}$ (dose escalation). Two (2) hours after injection of the radiolabeled peptide, the mice were euthanized with $\mathrm{CO}_{2} / \mathrm{O}_{2}$. Blood was collected by cardiac puncture, and tissues (tumor, muscle, lung, spleen, kidney, liver, small intestine) were dissected, counted, and weighed. 
The effect of dose fractionation on the biodistribution of ${ }^{111}$ In-DOTA-E-[c(RGDfK) $]_{2}$ was studied in two groups of mice who received four injections with $1 \mu \mathrm{g}$ of nonradioactive DOTA-E$[\mathrm{c}(\mathrm{RGDfK})]_{2}$ with intervals of 1 hour or 2 hour. One (1) or 2 hours after the fourth injection, the mice in these groups received $1 \mu \mathrm{g}$ of DOTA-E$[\mathrm{c}(\mathrm{RGDfK})]_{2}$ labeled with $0.4 \mathrm{MBq}{ }^{111} \mathrm{In}$. Two (2) hours after injection of the radiolabeled peptide, the mice were euthanized with $\mathrm{CO}_{2} / \mathrm{O}_{2}$. Blood was collected by cardiac puncture, and tissues (tumor, muscle, lung, spleen, kidney, liver, small intestine) were dissected and weighed.

The activity in tissues and injection standards was measured in a shielded well-type scintillation gamma counter (Wizard, Pharmacia, Turku, Finland) and expressed as \% ID/g.

\section{Peptide-Receptor Radionuclide Therapy}

The therapeutic efficacy of $37 \mathrm{MBq}{ }^{90} \mathrm{Y}$-DOTA$\mathrm{E}-[\mathrm{c}(\mathrm{RGDfK})]_{2}$ (specific activity: $7.4 \mathrm{MBq} / \mu \mathrm{g}$ ) administered as one bolus injection was compared to the therapeutic efficacy of the same dose of ${ }^{90} \mathrm{Y}$-DOTA-E-[c(RGDfK) $]_{2}$ administered in five equal portions. Four groups of 10 mice with s.c. NIH:OVCAR-3 tumors were used in this experiment (Groups A-D). Group A received 37 MBq ${ }^{90}$ Y-DOTA-E-[c(RGDfK) $]_{2}$ (peptide dose: $5.0 \mu \mathrm{g})$ as a single bolus injection $(0.2 \mathrm{~mL})$. Group B received the same dose of ${ }^{90} \mathrm{Y}$-DOTA$\mathrm{E}-[\mathrm{c}(\mathrm{RGDfK})]_{2}$ administered in 5 equal portions $(5 \times 7.4 \mathrm{MBq} ; 5 \times 1.0 \mu \mathrm{g})$ with a 1 -hour interval between the five injections. The mice in group $\mathrm{C}$ received 5 equal doses of the scrambled sequence control peptide ${ }^{90} \mathrm{Y}$-DOTA-E$[\mathrm{c}(\mathrm{RGKfD})]_{2}(5 \times 7.4 \mathrm{MBq}, 5 \times 1.0 \mu \mathrm{g}, 1$-hour interval). The mice in group $\mathrm{D}$ received 5 subsequent injections with nonradioactive DOTA-E$[\mathrm{c}(\mathrm{RGKfD})]_{2}$ peptide $(5 \times 1.0 \mu \mathrm{g}, 1$-hour interval) and also a served as a control group.

The size of the tumors was measured twice weekly in 3 dimensions using a caliper. The volume was estimated assuming the tumors were elipsoids, using the formula: volume $=4 / 3 \pi \times$ $1 / 2$ length $\times 1 / 2$ width $\times 1 / 2$ height. At the time of the injection the volume of the s.c. tumors ranged from 27 to $150 \mathrm{~mm}^{3}$. When the volume of the tumors exceeded $2 \mathrm{~cm}^{3}$, the mice were taken out of the experiment and euthanized.

\section{Statistical Analysis}

Statistical analysis was performed using a GraphPad Prism 3.0 (GraphPad Software, San Diego,
CA). The biodistribution data were analyzed using the one-way analysis of variance ANOVA test. The level of significance was set at $p=0.05$. If $p<0.05$, Tukey-Kramer multiple comparisons post-tests were performed.

\section{RESULTS}

\section{Radiolabeled Peptides}

RP-HPLC analysis indicated that the radiochemical purity of DOTA-E-[c(RGDfK) $]_{2}$ labeled with ${ }^{111} \mathrm{In}$ and ${ }^{90} \mathrm{Y}$ was $96 \%$ and $95 \%$, respectively. The $\alpha_{\mathrm{v}} \beta_{3}$ binding capacity of the ${ }^{111}$ In-labeled peptide was confirmed in an in vitro cell binding assay on IGROV-1 human ovarian carcinoma cells as described previously. ${ }^{10}$

\section{Peptide-Dose Escalation Study}

The biodistribution of ${ }^{111}$ In-DOTA-E-[c(RGDfK) $]_{2}$ in athymic mice with s.c. OVCAR-3 tumors at a peptide dose of $1.0 \mu \mathrm{g}$ per mouse is shown in Figure 1. Two (2) hours after injection, the highest activity concentration was found in the tumor: $4.73 \pm 0.65 \% \mathrm{ID} / \mathrm{g}$. The ${ }^{111} \mathrm{In}$-labeled peptide cleared very rapidly from the blood $(0.08 \% \mathrm{ID} / \mathrm{g}$, 2 hour p.i.), and consequently the tumor-to-blood ratio in these mice was relatively high $(63 \pm 5)$.

The effect of the peptide dose on the biodistribution of ${ }^{111}$ In-DOTA-E-[c(RGDfK) $]_{2}$ is shown in Table 1. Highest uptake in the tumor was found at peptide doses of 0.5 and $1.0 \mu \mathrm{g}(4.87 \pm 0.60$ $\% \mathrm{ID} / \mathrm{g}$ and $4.73 \pm 0.65 \% \mathrm{ID} / \mathrm{g}, \mathrm{p}>0.05$ ) (Fig. 2). Uptake at peptide doses of 2.0, 5.0, and $10 \mu \mathrm{g}$ $(3.20 \pm 0.26 \% \mathrm{ID} / \mathrm{g}, 2.07 \pm 0.46 \% \mathrm{ID} / \mathrm{g}, 1.54 \pm$ $0.15 \% \mathrm{ID} / \mathrm{g}$, respectively) was significantly lower $(p<0.01)$, most likely due to saturation of accessible $\alpha_{\mathrm{v}} \beta_{3}$ integrin expressed in the tumor. The uptake of ${ }^{111}$ In-DOTA-E-[c(RGDfK) $]_{2}$ in the normal tissues (muscle, lung, liver, spleen, and intestine) also was reduced at the higher peptide doses, suggesting that the localization of the peptide in these normal tissues was also receptor-mediated and saturable (Table 1).

Interestingly, when fractionating the $5.0 \mu \mathrm{g}$ peptide dose in 5 fractions of $1.0 \mu \mathrm{g}$ each, the uptake in tumor of the last $1.0-\mu \mathrm{g}$ dose was higher than that of the 5.0- $\mu \mathrm{g}$ dose bolus injection $(3.18 \pm 0.56 \% \mathrm{ID} / \mathrm{g}$ versus $2.07 \pm 0.46$ $\% \mathrm{ID} / \mathrm{g}, p<0.05)$. However, the tumor uptake of the last fraction of the fractionated dose was significantly lower than that of a single dose of 1.0 $\mu \mathrm{g} \quad(3.18 \pm 0.56 \% \mathrm{ID} / \mathrm{g}$ versus $4.73 \pm 0.65$ 
$\% \mathrm{ID} / \mathrm{g}, p<0.01)$. The uptake of the fractionated dose was not affected by the time interval between the injections ( 1 hour or two h, $p>0.05$ ).

\section{Peptide-Receptor Radionuclide Therapy}

The MTD of ${ }^{90}$ Y-DOTA-E- $[\mathrm{c}(\mathrm{RGDfK})]_{2}$ in this mouse model is $37 \mathrm{MBq}$ per mouse as determined previously. The maximum specific activity of ${ }^{90} \mathrm{Y}$-labeled DOTA-E-[c(RGDfK) $]_{2}$ is $7.4 \mathrm{MBq} /$ $\mu \mathrm{g}$. Therefore, the MTD of the peptide has to be administered with a peptide dose of at least 5.0 $\mu \mathrm{g}$. The biodistribution experiments indicated that $5.0 \mu \mathrm{g}$ of peptide can be targeted more efficiently to the OVCAR-3 tumor in this mouse model when administered as a fractionated dose $(5 \times 1.0 \mu \mathrm{g})$. Therefore, the therapeutic efficacy of a single bolus injection of $37 \mathrm{MBq}{ }^{90} \mathrm{Y}$-labeled DOTA-E-[c(RGDfK) $]_{2}$ was compared to that of the same-activity dose administered as five subsequent injections with a 1-hour time interval in a peptide-receptor radionuclide therapy experiment (Fig. 3).

Dose fractionation of the activity dose of 37 $\mathrm{MBq}$ of ${ }^{90} \mathrm{Y}$ - DOTA-E- $[\mathrm{c}(\mathrm{RGDfK})]_{2}$ in five equal portions did not improve the growth-inhibitory effect of the radionuclide therapy compared to therapy with $37 \mathrm{MBq}$ of ${ }^{90}$ Y-DOTA-E$[\mathrm{c}(\mathrm{RGDfK})]_{2}$ administered in one injection of 5.0 $\mu \mathrm{g}$ of peptide. The growth rate of the tumors in both of these groups was significantly delayed compared to the growth of the tumors in the mice that received ${ }^{90}$ Y-labeled scrambled control peptide or nonradioactive peptide.

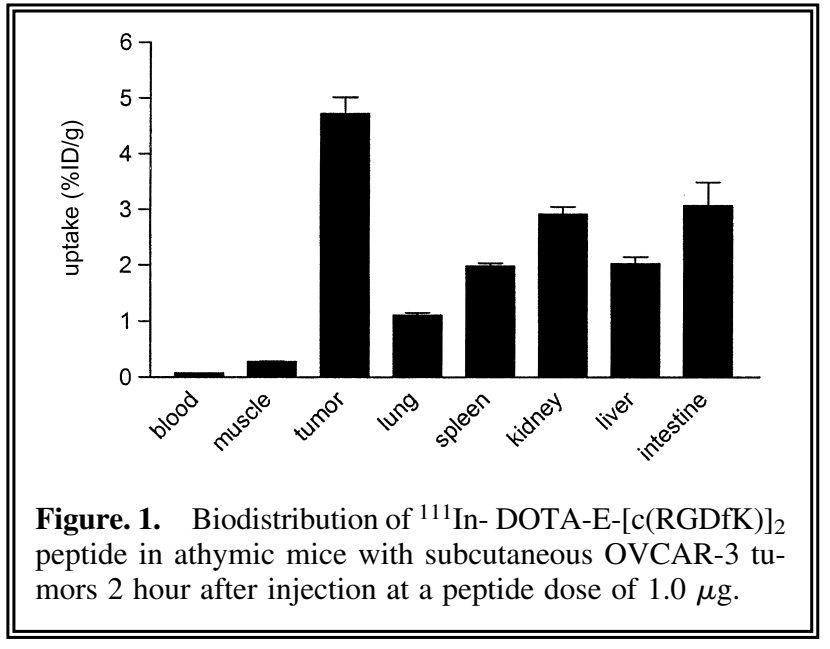

\section{DISCUSSION}

The present study aimed to optimize peptide-receptor radionuclide therapy with a ${ }^{90} \mathrm{Y}$-labeled dimeric cyclic RGD peptide using rapid-dose fractionation. The maximum specific activity of the ${ }^{90}$ Y-labeled DOTA-E- $[\mathrm{c}(\mathrm{RGDfK})]_{2}$ peptide that we use for peptide receptor radionuclide therapy is $7.4 \mathrm{MBq} / \mu \mathrm{g}$, while a total activity dose of $37 \mathrm{MBq}$ can be administered safely to mice. Therefore, a $37 \mathrm{MBq}$ dose contains at least 5.0 $\mu \mathrm{g}$ of the DOTA-E-[c(RGDfK) $]_{2}$ peptide. However, the peptide dose escalation study indicated that, at peptide doses exceeding $1.0 \mu \mathrm{g} /$ mouse, the uptake in the tumor decreased, most likely due to saturation of the $\alpha_{\mathrm{v}} \beta_{3}$ binding sites in the

Table 1. Biodistribution (\% ID/g $\pm \mathrm{SD})$ of ${ }^{111} \mathrm{In}-\mathrm{DOTA}-\mathrm{E}-[\mathrm{c}(\mathrm{RGDfK})]_{2}$ at Various Peptide Doses in Athymic Mice with Subcutaneous OVCAR-3 Tumors $2 \mathrm{H}$ after Injection

\begin{tabular}{|c|c|c|c|c|c|c|c|}
\hline \multirow[b]{2}{*}{ Organ } & \multicolumn{7}{|c|}{ Dose } \\
\hline & $0.5 \mu g$ & $1.0 \mu g$ & $2.0 \mu g$ & $5.0 \mu g$ & $10 \mu g$ & $\begin{array}{l}5 \times 1.0 \mu g \\
1-h \text { interval }\end{array}$ & $\begin{array}{l}5 \times 1.0 \mu g \\
2-h \text { interval }\end{array}$ \\
\hline Blood & $0.12 \pm 0.02$ & $0.08 \pm 0.01$ & $0.08 \pm 0.01$ & $0.06 \pm 0.01$ & $0.06 \pm 0.01$ & $0.05 \pm 0.01$ & $0.05 \pm 0.01$ \\
\hline Muscle & $0.42 \pm 0.02$ & $0.28 \pm 0.03$ & $0.27 \pm 0.07$ & $0.13 \pm 0.01$ & $0.16 \pm 0.08$ & $0.29 \pm 0.11$ & $0.28 \pm 0.06$ \\
\hline Tumor & $4.87 \pm 0.60$ & $4.73 \pm 0.65$ & $3.20 \pm 0.26$ & $2.07 \pm 0.46$ & $1.54 \pm 0.15$ & $3.28 \pm 0.60$ & $3.18 \pm 0.56$ \\
\hline Lung & $0.97 \pm 0.07$ & $1.11 \pm 0.09$ & $0.72 \pm 0.08$ & $0.47 \pm 0.09$ & $0.44 \pm 0.06$ & $0.70 \pm 0.10$ & $0.64 \pm 0.01$ \\
\hline Spleen & $2.03 \pm 0.08$ & $1.99 \pm 0.11$ & $1.50 \pm 0.20$ & $1.14 \pm 0.15$ & $0.79 \pm 0.03$ & $1.58 \pm 0.12$ & $1.23 \pm 0.10$ \\
\hline Kidney & $2.91 \pm 0.11$ & $2.93 \pm 0.28$ & $2.37 \pm 0.36$ & $2.04 \pm 0.18$ & $2.26 \pm 0.12$ & $2.08 \pm 0.14$ & $1.93 \pm 0.25$ \\
\hline Liver & $2.18 \pm 0.08$ & $2.03 \pm 0.26$ & $1.55 \pm 0.24$ & $0.93 \pm 0.10$ & $0.70 \pm 0.08$ & $1.50 \pm 0.19$ & $1.17 \pm 0.14$ \\
\hline Intestine & $3.46 \pm 0.37$ & $3.08 \pm 0.92$ & $2.51 \pm 0.39$ & $1.61 \pm 0.30$ & $1.06 \pm 0.14$ & $2.25 \pm 0.30$ & $1.93 \pm 0.29$ \\
\hline
\end{tabular}

In the two groups of mice that received a fractionated dose $(5 \times 1.0 \mu \mathrm{g})$, the biodistribution of the fifth fraction of the dose is shown. 


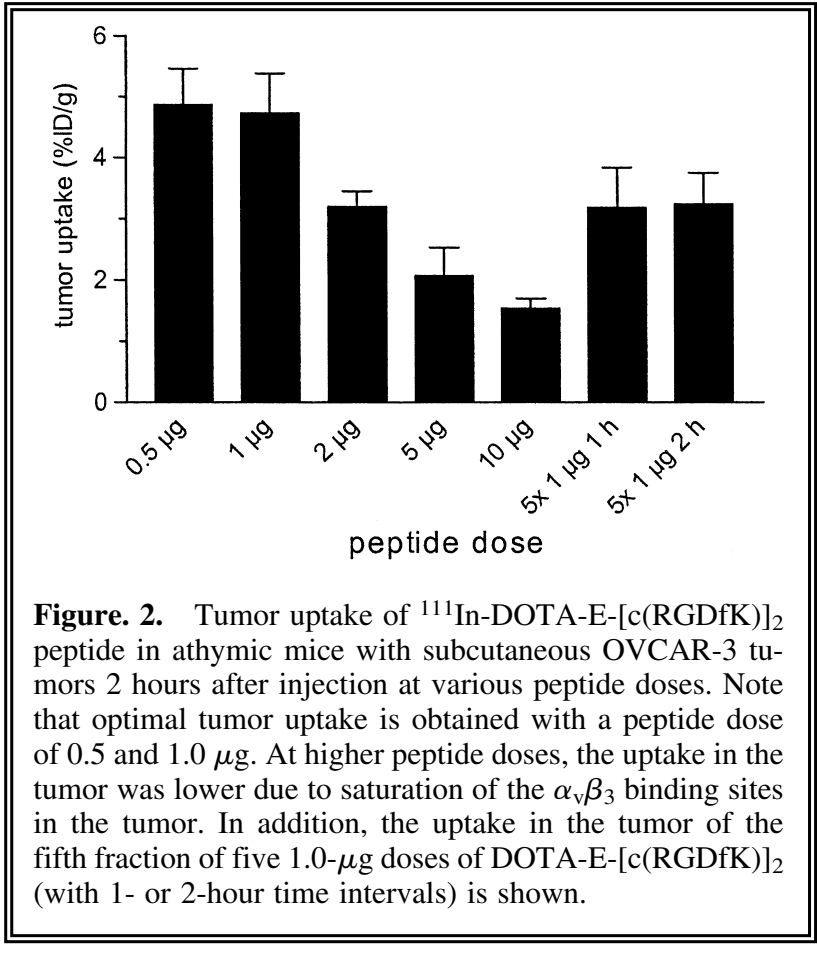

tumor. Similarly, the uptake in most normal tissues tested (lung, spleen, kidney, liver, and intestine) was significantly lower at the higher peptide doses. This observation was in line with earlier studies in which we showed that part of the uptake of the peptide in normal tissues can be blocked with an excess of cold peptide, ${ }^{10}$ indicating that the uptake in these tissues is sat- urable. Whether this is due to expression of $\alpha_{\mathrm{v}} \beta_{3}$ integrin in these tissues remains to be investigated.

When the 5.0- $\mu \mathrm{g}$ dose was administered in five equal portions with a 1- or 2-hour time interval, the uptake in the tumor of the last $1.0-\mu \mathrm{g}$ portion $(3.2 \pm 0.2 \% \mathrm{ID} / \mathrm{g})$ was significantly higher than that of the $5.0-\mu \mathrm{g}$ dose injected as a bolus $(2.1 \pm$ $0.5 \% \mathrm{ID} / \mathrm{g})$. These data indicate that the uptake of the $5 \times 1.0 \mu \mathrm{g}$-dose was even higher, because the uptake of the first $1.0-\mu \mathrm{g}$ fraction in the tumor was $4.7 \pm 0.6 \% \mathrm{ID} / \mathrm{g}$. These results indicate that the mean uptake of the $5 \times 1.0-\mu \mathrm{g}$ dose is approximately $4.0 \% \mathrm{ID} / \mathrm{g}$, being the mean tumor uptake of the first and the fifth dose. Thus, the biodistribution study showed that rapid-dose fractionation can increase the uptake of the radiolabeled peptide almost twofold. These data suggest that within 1 hour after targeting the $\alpha_{\mathrm{v}} \beta_{3}$ binding sites in the tumor with the RGD-peptide, new $\alpha_{\mathrm{v}} \beta_{3}$ binding sites are available for binding newly administered RGD-peptide.

Despite the fact that peak tumor uptake of the radiolabeled peptide was higher when the fractionated dose scheme was applied, the therapeutic effect of $37 \mathrm{MBq}{ }^{90}$ Y-DOTA-E-[c(RGDfK) $]_{2}$ was not enhanced significantly when administered as 5 equal fractions of $7.4 \mathrm{MBq}$. This could be due to the fact that the therapeutic effect of ${ }^{90}$ Y-DOTA-E-[c(RGDfK) $]_{2}$ administered as a single bolus was considerable.

Various studies have investigated the potential of dose fractionation in radionuclide therapy. The

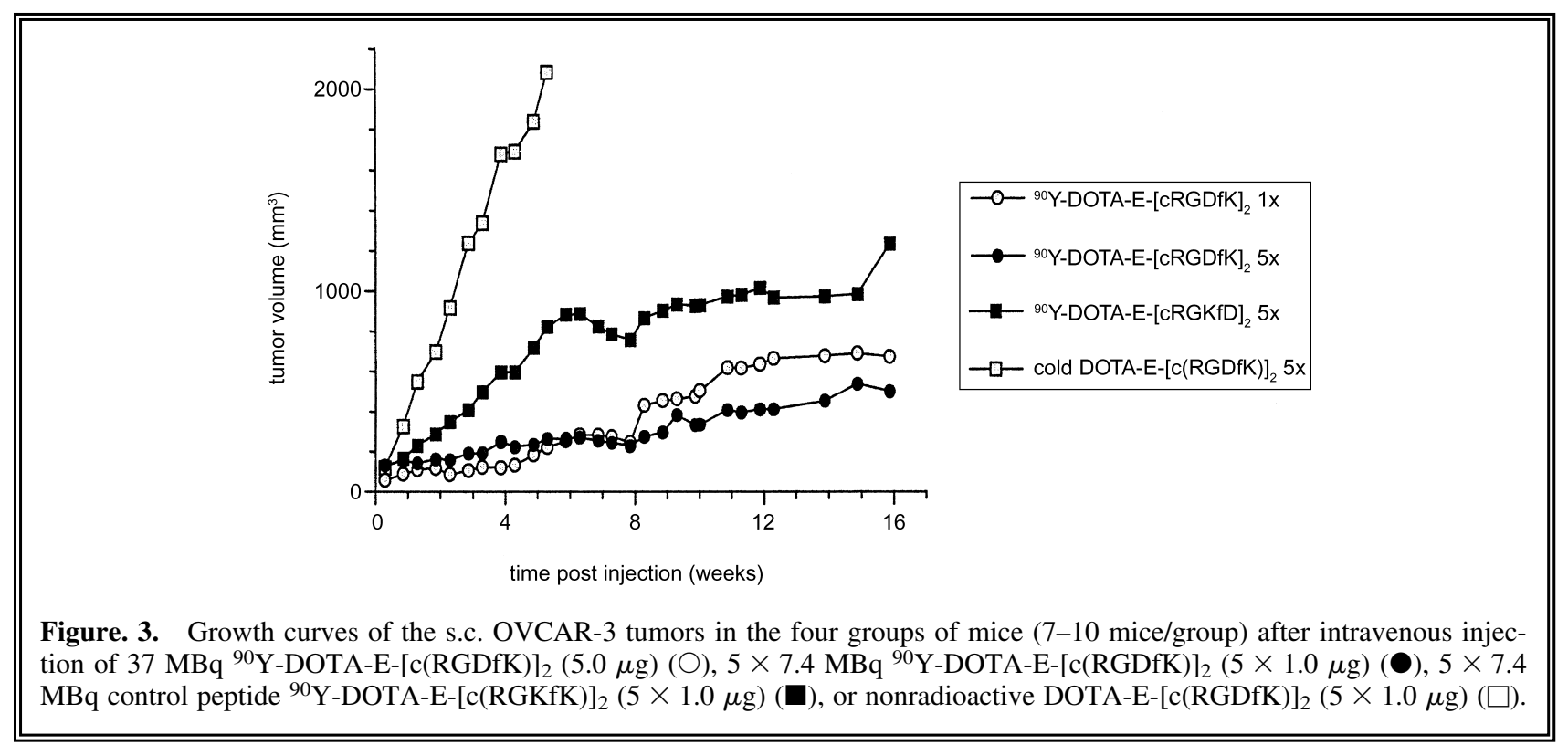


rationale and the design of these studies varied largely. Several studies aimed to overcome heterogeneity of intratumoral distribution of the radionuclide and the consequent nonuniformity of tumor radiation doses. ${ }^{14,15}$ Other studies aimed to reduce marrow toxicity and thus to increase the total radioactivity dose that can be administered. ${ }^{16,17}$ Only a few studies aimed to enhance to radiation dose to the tumor and thus to enhance the therapeutic effect of the same activity dose administered as multiple injections. In mice with HeLa xenografts, the tumor targeting with 22 $\mathrm{MBq}{ }^{125}$ I-labeled anti-cytokeratin monoclonal antibody administered as one, three, or ten injections was investigated. ${ }^{18}$ In contrast with our findings, these investigators found reduced uptake in the tumors when the dose was administered in multiple injections. However, in that study the time interval between the injections was much longer and the antibody protein dose did not saturate the target antigen in the tumor. Goel et al. described a study in mice with LS174T tumors in which the researchers compared the therapeutic efficacy of an activity dose of $37 \mathrm{MBq}{ }^{131} \mathrm{I}$ labeled CC49 antibody construct either as a single bolus or as 4 injections $(4 \times 0.25 \mathrm{MBq})$ with a 1 day time interval. ${ }^{19}$ They found that the therapeutic efficacy of the fractionated dose was significantly higher than that of the single injection.

In conclusion, the present study shows that rapiddose fractionation can improve the targeting of $\alpha_{\mathrm{v}} \beta_{3}$-expressing tumors with radiolabeled dimeric cyclic RGD peptide. Our studies suggest that 1 hour after targeting the $\alpha_{\mathrm{v}} \beta_{3}$ binding sites in the tumor with the RGD-peptide, new $\alpha_{\mathrm{v}} \beta_{3}$ binding sites are available again for binding RGD peptides.

\section{ACKNOWLEDGMENTS}

The authors thank G. Grutters and H. Eikholt (Central Animal Facility) for professional assistance during the animal experiments.

\section{REFERENCES}

1. Cheresh DA. Integrins: Structure, function and biological properties. Adv Mol Cell Biol 1993;6:225.

2. Brooks PC. Role of integrins in angiogenesis. Eur $J$ Cancer 1996;32A:2423.

3. Fiedler W, Graeven U, Ergun S, et al. Vascular endothelial growth factor, a possible paracrine growth factor in human acute myeloid leukemia. Blood 1997; 89:1870.
4. Foss HD, Araujo I, Demel G, et al. Expression of vascular endothelial growth factor in lymphomas and Castelman's disease. J Pathol 1997;183:44.

5. PerezAtayde AR, Sallan SE, Tedrow U, et al. Spectrum of tumor angiogenesis in the bone marrow of children with acute lymphoblastic leukemia. Am J Pathol 1997; 150:815.

6. Folkman J. Angiogenesis in cancer, vascular, rheumatoid and other disease. Nat Med 1995;1:27.

7. Haubner R, Wester HJ, Reuning U, et al. Radiolabeled alpha(v)beta(3) integrin antagonists: A new class of tracers for tumor targeting. J. Nucl Med 1999;40:1061.

8. Haubner R, Wester H-J, Burkhart F, et al. Glycosylated RGD-containing peptides: Tracer for tumor targeting and angiogenesis imaging with improved biokinetics. J Nucl Med 2001;42:326.

9. Van Hagen PM, Breeman WA, Bernard HF, et al. Evaluation of a radiolabelled cyclic DTPA-RGD analogue for tumour imaging and radionuclide therapy. Int J Cancer 2000;90:186.

10. Janssen ML, Oyen WJ, Dijkgraaf I, et al. Tumor targeting with radiolabeled alpha-v-beta-3 integrin binding peptides in a nude mouse model. Cancer Res 2002;62:6146.

11. Janssen ML, Oyen WJ, Massuger LF, et al. Comparison of a monomeric and dimeric radiolabeled RGD-peptide for tumor targeting. Cancer Biother Radiopharm 2002; 17:641.

12. Liu S, Cheung E, Ziegler M, et al. ${ }^{90} \mathrm{Y}$ and ${ }^{177} \mathrm{Lu}$ labeling of a DOTA-conjugated vitronectin receptor antagonist useful for tumor therapy. Bioconjugate Chem 2001;12:559.

13. Barrett JA, Crocker AC, Lazewatsky J, et al. RP697, a ${ }^{90} \mathrm{Y}$-labeled alpha-v-beta-3 antagonist, demonstration of bioequivalence with ${ }^{111}$ In-RP686 and efficacy in dogs. Cancer Res 2001;42:94.

14. DeNardo GL, Schlom J, Buchsbaum DJ, et al. Rationales, evidence, and design considerations for fractionated radioimmunotherapy. Cancer 2002;94:1332.

15. O'Donoghue JA, Sgouros G, Divgi CR, et al. Singledose versus fractionated radioimmunotherapy: model comparisons for uniform tumor dosimetry. $\mathrm{J} \mathrm{Nucl} \mathrm{Med}$ 2000;41:538.

16. Shen S, Duan J, Meredith RF, et al. Model prediction of treatment planning for dose-fractionated radioimmunotherapy. Cancer 2002;94(4[suppl]): 1264.

17. Buchsbaum D, Khazaeli MB, Liu T, et al. Fractionated radioimmunotherapy of human colon carcinoma xenografts with ${ }^{131}$ I-labeled monoclonal antibody CC49. Cancer Res 1995;55(23[suppl]):5881S.

18. Ullen A, Sandstrom P, Rossi Norrlund R, et al. Dosimetry of fractionated administration of ${ }^{125}$ I-labeled antibody at experimental radioimmunotargeting. Cancer 1997;80(12[suppl]):2510.

19. Goel A, Augustine S, Baranowska-Kortylewicz J, et al. Single-dose versus fractionated radioimmunotherapy of human colon carcinoma xenografts using ${ }^{131}$ I-labeled multivalent CC49 single-chain fvs. Clin Cancer Res 2001;7:175. 